\title{
Hepatoprotective activity and constituents of Nigrospora sp. CMH2_13: An endophytic fungus isolated from leaves of Phyllanthus amarus Schum. and Thonn.
}

\author{
Smita K. Puri*, Prasanna V. Habbu, Preeti V. Kulkarni*, Arun B. Joshi**, V. H. Kulkarni* and Sheshagiri R Dixit*** \\ P.G. Department of Pharmacognosy and Phytochemistry, SET's College of Pharmacy, S R Nagar, Dharwad-580002, Karnataka, India \\ *P.G. Department of Pharmacology, SET'S College of Pharmacy, $S$ R Nagar, Dharwad-580002, Karnataka, India \\ **P.G. Department of Pharmacognosy and Phytochemistry, Government College of Pharmacy, 18th June Road, Panji, Goa-403001, India \\ ***Depratment of Pharmaceutical Chemistry, JSS College of Pharmacy, Mysuru, JSSAHER, S S Nagar, Mysuru-570015, Karnataka, India
}

\section{Article Info}

Article history

Received 5 October 2020

Revised 21 November 2020

Accepted 23 November 2020

Published online 30 December 2020

\section{Keywords}

Endophytic fungi

Hepatoprotective

Phyllanthus amarus Schum. and

Thonn.

Nigrospora sp. CMH2

Phyllanthin

Hypophyllanthin

Secondary metabolite

\begin{abstract}
Endophytes are microorganisms that dwell within plant tissues by having a symbiotic association, one of the sources of secondary metabolites in plants. In this study, an attempt was made to isolate, characterize endophytic fungi, from leaves of Phyllanthus amarus Schum. and Thonn., and to screen the fungal fractions for hepatoprotective activity, followed by isolation of secondary metabolites from the endophytic fraction. An endophytic fungus, PALF-2 was identified as Nigrospora sp. CMH2 by molecular characterization. PALF-2 was fermented to get ethyl acetate (P2EA) and n butanol (P2nB) fractions. P2EA and P2nB were evaluated for hepatoprotective activity against paracetamol-induced hepatotoxicity. Based on the activity, P2EA was subjected to column chromatography and analyzed by spectroscopic methods. P2EA and $\mathrm{P} 2 \mathrm{nB}$ at doses of 50 and $100 \mathrm{mg} / \mathrm{kg}$ reversed the elevated biochemical parameters as compared to $\mathrm{CCl}_{4}$ treated groups. $\mathrm{P} 2 \mathrm{EA}$ and $\mathrm{P} 2 \mathrm{nB}$ restored endogenous enzyme levels. Chromatographic studies of P2EA led to the isolation of hypophyllanthin, phyllanthin, quercetin-3, 4di-O-glucoside, and kaempferol-3-O-rutinoside, the structures were confirmed by spectroscopic analysis. LC-MS studies of the oil confirmed the presence of seven constituents. This is the first report on the isolation of these constituents from the endophytic fungus of $P$. amarus. Thus, it can be concluded that, Nigrospora sp. CMH2_13 could be a good commercial source for the production of hepatoprotective and antioxidant constituents.
\end{abstract}

\section{Introduction}

Microbial community has the capability to colonize plants which assist them in healthy growth of the plant. Depending on the plant environment, plants get colonized by pathogens and nonpathogenic endophytes, as they occupy part of their life cycle inner surface of the plants (Brader et al., 2017). Medicinal plants are known to nurture potent endophytic micro-organisms, due to the presence of secondary metabolites. Thus, they constitute a fascinating source of natural metabolites. Reports exhibited that several medicinal plants get colonized by endophytes. These are the micro-organisms that reside in tissues of living plants and act to improve their growth (Pedra et al., 2018). Bioactive compounds obtained from the endophytes are valuable in biotechnological applications, inoculation of either these microbes or constituents helps in improving plant health. Endophytes have an important role in abiotic stress management and can withstand during drought conditions (Barkodia et al., 2018).

Corresponding author: Ms. Smita K. Puri

P.G. Department of Pharmacognosy and Phytochemistry, SET's College of Pharmacy, S R Nagar, Dharwad-580002, Karnataka, India E-mail: smitamadagundi@gmail.com

Tel.: +91-9986033439

Copyright $(\odot) 2020$ Ukaaz Publications. All rights reserved.

Email: ukaaz@yahoo.com; Website: www.ukaazpublications.com
Phyllanthus is the important group of plants in India. Phyllanthus amarus Schum. and Thonn. is being distributed as a weed in waste and cultivated lands (Meena et al., 2018). P. amarus, historically has been used by people, because of its rich medicinal values. P. amarus (family Euphorbiaceae) is a plant traditionally used in the treatment of viral hepatitis in India (Kiemer et al., 2003). P. amarus contains hypophyllanthin, phyllanthin, niranthin, kaempferol, niranthin, nirtetralin, isobubbialine, epibubbialine, securinine, nor-securinine, dihydrosecurinine, geraniin, corilagin, 1,6-digalloylglucopyranoside rutin, quercetin 3-O glucopyranoside, amarulone, phyltetralin, demethylenedioxy-astragalin, etc., chemical constituents in its different parts (Yoganarasimhan, 1996; Gupta and Vaghela, 2019). P. amarus are rich in secondary metabolites and are the key factors for various pharmacological activities such as antidiabetic, antitumor, immunomodulation, antifungal, antibacterial and anti-inflammation activities and antioxidant effects (Meena et al., 2018).

Reports revealed the presence of triterpenoids including cycloeucalenyl acetate, ergosta-5,7,22-trien-3-ol acetate, macdougallin, 17-(1,5-Dimethylhexyl)-6- hydroxy-5-methylestr9 -en-3-yl acetate, steroids such as stigmasterol and $\beta$-sitosterol in the hexane fraction, 6,7-epoxypregn-4-ene-9,11,18-triol-3,20dione,11,18-diacetate, bufalin, olean-13(18)-ene, methyl ursolate, barringenol R1 and 7,8-epoxylanostan-11-ol,3-acetoxy in the 
methanol fraction (Zubair et al., 2017). One endophytic fungus, namely; Acinetobacter sp., and one endophytic bacteria namely; Bacillus sp. were isolated from leaves of $P$. amarus and identified by 16s rRNA sequencing (Joe et al., 2016). Thirteen fungal species of endophytic fungi were isolated and reported from stems and roots of $P$. amarus (Kandasamy et al., 2017). The other endophytic fungi isolated from $P$. amarus showed antibacterial activity against gram (+) and gram (-) bacteria (Sowparthani and Kathiravan, 2011). Literature survey revealed, no work has been reported associated with in vitro antioxidant, in vivo hepatoprotective activity and isolation of secondary metabolites from endophytic fungi of $P$. amarus leaves. So, a venture was made for the study.

\section{Materials and Methods}

\subsection{Materials}

All the chemicals and reagents (analytical grade) were purchased from Sigma Aldrich (Dorset, UK) and Hi Media for extraction and chromatographic studies. Melting points of all the isolated compounds were determined by Shital-digital programmable melting point apparatus. IR spectra were recorded using Bruker FT-IR. Proton and ${ }^{13} \mathrm{C}$ NMR spectra for isolated compounds were obtained using a Bruker Avance 500 NMR spectrophotometer. Chemical shifts are reported in $\delta(\mathrm{ppm})$. A mass spectrum was recorded using XEVO G2XS QTOF mass spectrophotometer by studying $\mathrm{m} / \mathrm{z}$.

\subsection{Isolation of endophytic fungi}

Healthy stems and leaves of Phyllanthus amarus Schum. and Thonn. were collected from the surroundings of Dharwad, Karnataka, India. The plant was identified and authenticated by a Taxonomist, Department of Botany, Government Science College, Dharwad, Karnataka, India and a voucher specimen (SETCPD/Ph.cog/herb/ $86 / 12 / 2017$ ) was deposited at the herbarium of the Postgraduate Department of Pharmacognosy and Phytochemistry, SET's College of Pharmacy, Dharwad, India. Briefly, plant materials were washed thoroughly in sterile water to remove adhered foreign material, surface disinfected by soaking in $70 \%$ ethanol for $3 \mathrm{~min}$ and $4 \%$ sodium hypochlorite $(\mathrm{NaOCl})$ for $1 \mathrm{~min}$, rinsed in sterile demineralized water and stored aseptically. The washings were tested to ascertain proper surface sterilization. Small pieces of inner tissues $(1 \mathrm{~cm} \mathrm{x}$ $1 \mathrm{~cm}$ ) were permeated on potato dextrose agar (PDA), supplemented with antibiotic streptomycin $(125 \mu \mathrm{g} / \mathrm{ml})$ in petri plates and incubated at $27^{\circ} \mathrm{C} \pm 2{ }^{\circ} \mathrm{C}$ until fungal growth was initiated. The purity of fungal colonies was checked randomly and grouped according to colony morphology. Purified strains were stored on PDA slants at $4{ }^{\circ} \mathrm{C}$ until further use (Sowparthani and Kathiravan, 2011; Katoch et al., 2014; Kandavel and Sekar, 2015; Puri et al., 2018).

\subsection{Molecular characterization of endophytic fungi by PCR sequential analysis}

Isolated fungal endophytes were identified using microscopic and molecular techniques. Using the genomic DNA fractionation kit (Bhat Biotech Ltd. Bangalore, India), genomic DNA was isolated from the given organism (Shukla et al., 2012). Phylogenetic analysis of endophytes was performed by the acquisition of ITS1-5.8SITS4 ribosomal gene sequencing. Internal transcribed spacer (ITS) region of the fungi was amplified using the forward primer ITS1 5'TCCGTAGGTGAACCTGCGG-3' and reverse primer ITS4 5'-
TCCTCCGCTTATTGATATGC-3' using polymerase chain reaction (PCR) as per the previously described method.

\subsection{Fermentation and preparation of endophytic fractions}

The purified fungal isolate was inoculated and fermented separately into a 3L Erlenmeyer flask containing $600 \mathrm{ml}$ of potato dextrose broth (PDB), incubated at $25^{\circ} \mathrm{C}-27^{\circ} \mathrm{C}$ for 21 days. After incubation, $500 \mathrm{ml}$ of chloroform was added to flask and left overnight. Further, homogenized at $4000 \mathrm{rpm}$ for $30 \mathrm{~min}$ to separate the mycelia from broth and filtered by Whatman filter paper under vacuum. Aqueous phase obtained after chloroform fraction was further partitioned three times with equal volumes of ethyl acetate, followed by two times partition with equal volumes of n-butanol. All the fractions were dried using rotary flash evaporator (SuperfitRotavap, PBU-6) and weighed (Kandavel and Sekar, 2015; Puri et al., 2018).

\subsection{Hepatoprotective activity of endophytic fractions}

Ethyl acetate (P2EA) and n-butanol fractions (P2nB) were screened for in vivo liver protective activity in $\mathrm{CCl}_{4}$ induced hepatotoxicity.

\subsection{Animals}

Albino Wister rats weighing 180-200 gm were used and procured from Aditya biosys Pvt. Ltd. Tumukuru, Karnataka, India and were housed in polypropylene cages containing sterile paddy husk as bedding under controlled conditions of temperature $23 \pm 2{ }^{\circ} \mathrm{C}$, controlled humidity of $60-70 \%$ and $12 \mathrm{~h}$ light and dark cycles in a registered animal house (Reg No.112/1999/CPCSEA, dated 19-051999). They were acclimatized for 7 days before the study. They had free access to standard nutritionally balanced pellets diet (VRK nutritional solutions, Sangli, India) and water ad libitum. Ethical clearance for animal studies was obtained from the Institutional Animal Ethical Committee and standard operating procedures and protocols were followed as per CPCSEA.

\subsection{Acute toxicity studies}

Swiss albino mice were used to determine the acute toxicity of $\mathrm{P} 2 \mathrm{EA}$ and $\mathrm{P} 2 \mathrm{nB}$. The animals were fasted for $12 \mathrm{~h}$ prior to the experiment were administered with a single dose $(2000 \mathrm{mg} / \mathrm{kg})$ of fractions dissolved in 5\% gum acacia and observed for mortality up to $48 \mathrm{~h}$ (short term toxicity). Based on the short-term toxicity, the dose of the next animal was determined as per OECD guideline 420 .

\subsection{Assessment of hepatoprotective activity}

Animals were divided randomly into six groups ( $\mathrm{n}=6$ animals per group)

Group I: (Normal control): Rats received distilled water $(2 \mathrm{ml} / \mathrm{kg}$, body weight, p.o) for the whole period of the experiment ( 5 days).

Group II: (Negative control): Rats administered with $\mathrm{CCl}_{4}$ in olive oil $\mathrm{v} / \mathrm{v}$ intraperitoneally $\left(2 \mathrm{ml} / \mathrm{kg}\right.$ body weight) on $2^{\text {nd }}$ and $4^{\text {th }}$ day.

Group III: (Positive control): Rats administered with $\mathrm{CCl}_{4}$ in olive oil $\mathrm{v} / \mathrm{v}$ intraperitoneally and treatment of Silymarin (100 mg/kg p.o.)

Group IV: (P2EA treated): Rats administered with $\mathrm{CCl}_{4}$ in olive oil $\mathrm{v} / \mathrm{v}$ intraperitoneally and treatment of P2EA $(50 \mathrm{mg} / \mathrm{kg} \mathrm{p.o.)}$

Group V: (P2EA treated): Rats administered with $\mathrm{CCl}_{4}$ in olive oil $\mathrm{v} / \mathrm{v}$ intraperitoneally and treatment of P2EA $(100 \mathrm{mg} / \mathrm{kg}$, p.o.) 
Group VI: (P2nB treated): Rats administered with $\mathrm{CCl}_{4}$ in olive oil $\mathrm{v} / \mathrm{v}$ intraperitoneally and treatment of $\mathrm{P} 2 \mathrm{nB}(50 \mathrm{mg} / \mathrm{kg}$, p.o. $)$

Group VII: (P2nB treated): Rats administered with $\mathrm{CCl}_{4}$ in olive oil $\mathrm{v} / \mathrm{v}$ intraperitoneal and treatment of $\mathrm{P} 2 \mathrm{nB}(100 \mathrm{mg} / \mathrm{kg}$, p.o.)

Treatment with respective drugs was continued for a period of five days as reported earlier (Shukla et al., 2012; Puri et al., 2018).

\subsection{Serum biochemical analysis}

The tail-snip method was used to collect the blood from all the experimental rats for biochemical estimations such as serum glutamic pyruvic transaminase (SGPT), Serum glutamic oxaloacetic transaminase (SGOT), Serum alkaline phosphatase (SALP), total bilirubin, direct bilirubin, triglycerides and total protein. Parameters in blood serum were estimated using semi-autoanalyser (Swemed Biomedicals Pvt. Ltd. ARTOS, India), following the manufacturer's protocol of standard kits (Swemed diagnostics, India).

\subsection{Measurement of enzymatic and non-enzymatic antioxidan activity}

Animals were euthanized and the whole liver was perfused in situ with ice cold saline, dissected out, blotted dry and immediately weighed. Liver homogenate $(10 \%)$ was prepared separately with ice cold saline EDTA using Teflon-glass homogenizer (Yamato LSG LH-21, Japan) used for the estimation of proteins and lipid peroxidation. The liver homogenate was centrifuged at 10,000 rpm for $10 \mathrm{~min}$ and the pellet discarded. The supernatant was again centrifuged at $20,000 \mathrm{rpm}$ for $1 \mathrm{~h}$ at $4^{\circ} \mathrm{C}$. Both the liver supernatants obtained were used for the estimation of nonenzymatic antioxidant (Lipid peroxidation) (Banerjee et al., 2008) and enzymatic antioxidants (Superoxide oxide dismutase and Catalase), following established methods reported (Flohe, 1984; Claiborne, 1985).

\subsection{Histopathological evaluation}

Livers were removed after the animal's euthanization and a portion of each tissue was fixed at $10 \%$ buffered neutral formalin and embedded in paraffin. Using microtome, solid sections of $5 \mu \mathrm{m}$ thickness were taken and stained with hematoxylin-eosin (H \& E) (Galigher and Kozloff, 1971). Histopathological changes were studied using Olympus Magnus microscope camera taking the help of a veterinarian pathologist.

\subsection{Statistical evaluation}

The data were expressed as Mean \pm standard error of means for each group. One analysis of variance (ANOVA), followed by Tukey's multiple comparison tests was used to calculate the statistical difference using Graph pad prism version 7.0 USA software. Values considered $p<0.05$ were considered statistically significant.

\subsection{Isolation of secondary metabolites from ethyl acetate fraction of Nigrospora sp. CMH2_13}

$20 \mathrm{~g}$ of the ethyl acetate fraction (P2EA) was mixed with $20 \mathrm{~g}$ of silica gel (60-120) mesh, using ethyl acetate as the solvent. The drug adsorbed silica was then loaded on top of the glass column which was previously packed with $200 \mathrm{~g}$ of silica gel (120) mesh using petroleum ether by wet packing method. The column was eluted first with $100 \%$ petroleum ether followed by Petroleum ether: chloroform graded mixtures $(95: 5,90: 10,80: 20,70: 30,60: 40$,
50:50) then with $100 \%$ chloroform followed by chloroform: ethyl acetate graded mixture $(95: 5,90: 10,80: 20,70: 30,60: 40,50: 50)$ then with $100 \%$ ethyl acetate, followed by ethyl acetate: $\mathrm{MeOH}$ graded mixture $(95: 5,90: 10,80: 20,70: 30,60: 40,50: 50)$ then with $100 \% \mathrm{MeOH}$. Each test tube contained $10 \mathrm{ml}$ of elutes which were concentrated and monitored by TLC (Silica Gel GF 254, visualization under UV ( 254 and $366 \mathrm{~nm}$ ). A total of 23 fractions were eluted out of which five fractions were collected in their pure form as a single spot.

Elutions were carried out with graded mixtures of petroleum ether: chloroform (50:50) resulted in a single spot as orange oil and monitored by gas chromatography, designated as PAE-1. Elutes obtained with chloroform: ethyl acetate (90:10) solvent was pooled together and concentrated to get a single spot as yellow crystals. A single spot was confirmed by TLC studies with mobile phase toluene: ethyl acetate (5:5) and detected in UV at $254 \mathrm{~nm}$, designated as PAE-2. Elutes obtained with chloroform: ethyl acetate (80:20) solvent resulted in a yellow crystallized compound which was rechromatographed and designated as PAE-3. Elutes obtained with ethyl acetate $(100 \%)$ solvent were pooled together and concentrated to get a single spot as a brown powder. A single spot was confirmed by TLC studies with mobile phase toluene: Ethyl acetate (3:7), detected in UV at $254 \mathrm{~nm}$, designated as PAE-4. Elutes obtained with ethyl acetate: $\mathrm{MeOH}(95: 5)$ solvent was pooled together and concentrated to get a single spot as a brown powder. A single spot was confirmed by TLC studies with mobile phase toluene: ethyl acetate (3:7) and detected in UV at $254 \mathrm{~nm}$, designated as PAE-5.

\subsection{Rechromatography of PAE-3}

$1 \mathrm{gm}$ of the fraction was adsorbed with $1 \mathrm{gm}$ of Silica gel for column chromatography (240-400 mesh). $20 \mathrm{~g}$ of Silica gel for column chromatography (240-400 mesh) with petroleum ether. Then it was eluted with the mobile phase to collect fractions and was concentrated. Each fraction was evaluated by TLC. Fractions showing the same number of spots and $\mathrm{R}_{f}$ values were pooled, concentrated and evaporated to dryness. The elutions were carried out with flow rate of 10 drops per min with $100 \%$ petroleum ether followed by petroleum ether: Chloroform graded mixtures (50:50), then with $100 \%$ chloroform followed by chloroform: ethyl acetate graded mixture $(99: 1,98: 2,96: 4,94: 6,92: 8,90: 10)$ then finally by $100 \%$ ethyl acetate. All the elutions were monitored by TLC (Silica gel GF 254; visualization by UV $254 \mathrm{~nm}, 366 \mathrm{~nm}$ ). Elutes obtained with 99:1, 98:2, 96:4, 94:6, 92:8 of chloroform: ethyl acetate resulted in a single prominent spot on TLC. A single spot was confirmed with mobile phase toluene: ethyl acetate (45:55) and detected in $\mathrm{UV}$ at $254 \mathrm{~nm}$ designated as PAE-3.

\section{Results}

\subsection{Identification of endophytic fungus}

Microscopic and molecular identification of the fungus confirmed that it belongs to the genus Nigrospora. The homology analysis based on phylogenetic tree revealed the best matching with Nigrospora sp. CMH2_13 (KF 227831.1).

\subsection{PCR sequential analysis of PALF-2}

The sequence of the ITS gene from PALF-2 and that of matching sequences from 10 nucleotide sequences were aligned by using the 
maximum likelihood method based on the Hasegawa Kishino Yano model. The tree shows the highest log likelihood (-601.8862). The sequence of the ITS gene for PALF-2 was compared with the existing sequence in the NCBI database using BLAST N programme. Based on these results, PALF-2 was identified as Nigrospora sp. CMH2_13 (Figure 1).

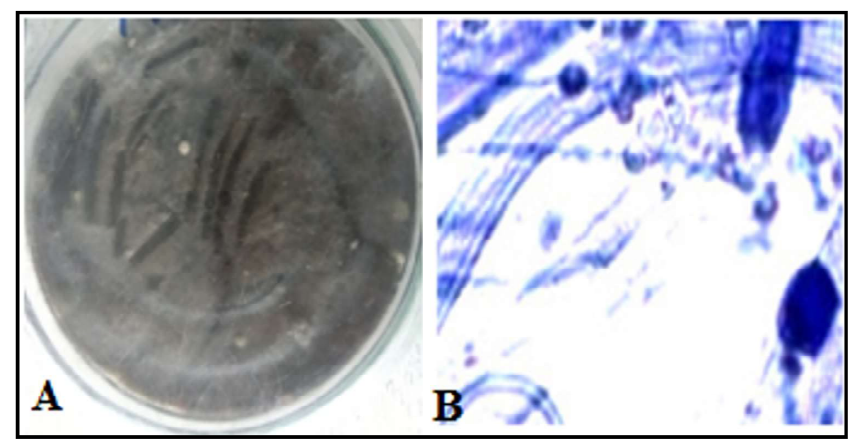

Figure 1: Colony morphology (A) and microphotograph of lactophenol cotton blue staining of colonies of Nigrosporasp.CMH2_13 observed on agar slant (B).

\subsection{Hepatoprotective activity of P2EA and P2nB}

\subsubsection{Acute toxicity $\left(\mathrm{LD}_{50}\right)$ studies}

Acute toxicity studies were performed following OECD guidelines (up and down method). No mortality was observed at $2000 \mathrm{mg} / \mathrm{kg}$ body weight after P2EA and $\mathrm{P} 2 \mathrm{nB}$ administration. To assess the hepatoprotective activity of P2EA and $\mathrm{P} 2 \mathrm{nB}$, doses of $50 \mathrm{mg} / \mathrm{kg}$ and $100 \mathrm{mg} / \mathrm{kg}$ body weight were selected, respectively.

\subsubsection{Effect of P2EA and P2nB on serum biochemical parameters}

Wister rats showed a significant elevation in the levels of serum ALT, AST, ALP, total and direct bilirubin, TG and total protein, following intoxication with $\mathrm{CCl}_{4},(2 \mathrm{ml} / \mathrm{kg}$ i.p. $)$ as compared to normal control. $\mathrm{A} \mathrm{CCl}_{4}$ stimulated an increase in the AST levels of rats was significantly reduced following treatment of animals with P2EA and $\mathrm{P} 2 \mathrm{nB}(50 \mathrm{mg} / \mathrm{kg}$ and $100 \mathrm{mg} / \mathrm{kg})$ and reference drug silymarin $(200 \mathrm{mg} / \mathrm{kg}$ p.o. $\left.){ }^{(* * *} p<0.001\right)$. Serum ALT, ALP, total and direct bilirubin, TG and total protein levels also showed a significant reduction, following treatment with different concentrations of P2EA and P2nB (Table 1).
3.3.3 Effect of P2EA and P2nB on endogenous antioxidant enzymes

Rats treated with $\mathrm{CCl}_{4}$ showed decreased SOD and CAT levels and a marked increase in LPO level in terms of TBARS as compared to control. P2EA and P2nB (100 mg/kg) decreased the elevated LPO level significantly $\left({ }^{* * *} p<0.001\right)$. P2EA ( 50 and $100 \mathrm{mg} / \mathrm{kg}$ ) and PA2nB $(100 \mathrm{mg} / \mathrm{kg})$ significantly increased the SOD and CAT levels $\left({ }^{* * *} p<0.001\right)$. The results are shown in Figure 2.

\subsection{Histopathological studies}

Histopathology of the liver treated with $\mathrm{CCl}_{4}$ showed significant induction of hyperplasia of the bile duct, interlobular fibrosis, vacuolation of hepatocytes and infiltration of lymphocytes. Treatment with P2EA and P2nB (50 and $100 \mathrm{mg} / \mathrm{kg}$ ) showed significant improvements in $\mathrm{CCl}_{4}$ induced injuries by reducing inflammatory responses, bile duct hyperplasia and interlobular necrosis followed by regeneration of hepatocytes (Figure 3).

\subsection{Secondary metabolites from Nigrospora sp. CMH2_13}

\subsubsection{LC-MS analysis of oil (PAE-1)}

LC-MS analysis of PAE-1 (orange oil) showed the presence of 7 components namely 1-dococene (a), hexadecanoic ethyl ester (b), ethyl oleate (c), oleic acid (d), cis vacceric acid (e), 1,2, benzene dicarboxylic acid dis octyl ester (f), oxalic acid allyl hexadecyl ester (g) (Figure 4). Structural confirmation of these components was done by comparing the data with the literature library.

\subsubsection{Quercetin-3, 4'-di-o-glucoside (PAE-2)}

Quercetin-3,4'-di-O-glucoside was obtained as yellow crystals, MP: $228^{\circ} \mathrm{C}-230^{\circ} \mathrm{C}: \mathrm{R}_{f}, 0.54\left(\mathrm{CHCl}_{3}\right.$ :EA, 90:10); IR (KBR) $\mathrm{cm}^{-1}$; $3390.86(\mathrm{OH}), 2939.52\left(\mathrm{CH}\right.$ str. of $\left.\mathrm{CH}_{3}\right), 1406.18$ ( $\mathrm{CH}$ deformation in $\left.\mathrm{CH}_{3}\right), 1211.30$ (C-O-C); ${ }^{1} \mathrm{H}$ NMR (DMSO D $):(500 \mathrm{MHZ}, \delta$ ppm) : $12.91\left(\mathrm{~s}, 2 \mathrm{H}, \mathrm{C}_{31}, \mathrm{C}_{32}-\mathrm{H}\right), 10.16\left(\mathrm{~s}, 2 \mathrm{H}, \mathrm{C}_{33}, \mathrm{C}_{34}-\mathrm{H}\right), 7.08\left(\mathrm{~s}, 1 \mathrm{H}, \mathrm{C}_{30}-\right.$ $\mathrm{H}), 6.98\left(\mathrm{~s}, 1 \mathrm{H}, \mathrm{C}_{12}-\mathrm{H}\right), 6.56-6.51\left(\mathrm{~m}, 3 \mathrm{H}, \mathrm{C}_{15}, \mathrm{C}_{16}, \mathrm{C}_{23}-\mathrm{H}\right), 6.21-$ $6.15\left(\mathrm{~m}, 2 \mathrm{H}, \mathrm{C}_{7}, \mathrm{C}_{9}-\mathrm{H}\right), 3.33\left(\mathrm{~s}, 4 \mathrm{H}, \mathrm{C}_{35}, \mathrm{C}_{36}, \mathrm{C}_{37}, \mathrm{C}_{39}-\mathrm{H}\right), 3.59(\mathrm{~s}, 4 \mathrm{H}$, $\left.\mathrm{C}_{40}, \mathrm{C}_{41}, \mathrm{C}_{42}, \mathrm{C}_{43}, \mathrm{C}_{44}-\mathrm{H}\right), 3.41\left(\mathrm{~s}, 5 \mathrm{H}, \mathrm{C}_{4}, \mathrm{C}_{38}, \mathrm{C}_{43}-\mathrm{H}\right), 2.51(\mathrm{~s}, 6 \mathrm{H}$, $\left.\mathrm{C}_{19}, \mathrm{C}_{20}, \mathrm{C}_{21}, \mathrm{C}_{26}, \mathrm{C}_{27}, \mathrm{C}_{28}-\mathrm{H}\right), 2.14\left(\mathrm{~s}, 6 \mathrm{H}, \mathrm{C}_{2}, \mathrm{C}_{3}, \mathrm{C}_{18}, \mathrm{C}_{22}, \mathrm{C}_{25}, \mathrm{C}_{29}-\right.$ H). ${ }^{13} \mathrm{C}$ NMR (DMSOD $)$ ): (100 MHZ, $\delta$ ppm): 168.97, 162.56, 161.33, $157.39,150.78,140.57,116.73,110.52,108.61,108.11,107.26$, 107.08, 105.74, 105.68, 104.94, 103.84, 97.38, 96.92, 77.80, 74.05, $73.16,71.68,61.49,56.60,56.56,20.64,20.38$. Mass spectra: ESIMS: found: $625.15\left(\mathrm{M}^{+}-1\right)$, calculated: $626.52\left(\mathrm{M}^{+}\right)$.

Table 1: Effect of P2EA and $\mathrm{P} 2 \mathrm{nB}$ on serum biochemical parameters in $\mathrm{CCl}_{4}$ induced hepatotoxicity in rats

\begin{tabular}{|c|c|c|c|c|c|c|c|c|}
\hline Groups & Dose & SGPT (mg/dl) & SGOT (mg/dl) & SALP (mg/dl) & $\begin{array}{l}\text { Total } \\
\text { bilirubin } \\
(\mathrm{mg} / \mathrm{dl})\end{array}$ & \begin{tabular}{|l} 
Direct \\
bilirubin \\
$(\mathrm{mg} / \mathrm{dl})$
\end{tabular} & $\begin{array}{l}\text { Triglycerides } \\
(\mathrm{mg} / \mathrm{dl})\end{array}$ & $\begin{array}{l}\text { Total protein } \\
(\mathrm{mg} / \mathrm{dl})\end{array}$ \\
\hline Control & $(2 \mathrm{ml} / \mathrm{kg})$ & & & & $0.35 \pm 0.01$ & $0.16 \pm 0.01$ & $58.06 \pm 0.46$ & $5.37 \pm 0.07$ \\
\hline $\mathrm{CCl}_{4}$ treated & $(2 \mathrm{ml} / \mathrm{kg})$ & $216.7 \pm 0.59^{* * *}$ & $271.1 \pm 0.87$ & $323.8 \pm 0.53$ & $1.03 \pm 0.01$ & $0.62 \pm 0.07$ & $105.01 \pm 1.31$ & $9.47 \pm 0.08$ \\
\hline Silymarin & $(25 \mathrm{mg} / \mathrm{kg})$ & $125.3 \pm 0.26^{* * *}$ & $186.1 \pm 0.51^{* * * *}$ & $276.2 \pm 0.77^{* * * *}$ & $0.73 \pm 0.01^{* * * *}$ & $0.43 \pm 0.02^{* * *}$ & $73.76 \pm 0.47^{* * *}$ & $4.48 \pm 0.07^{* * *}$ \\
\hline P2EA & $(50 \mathrm{mg} / \mathrm{kg})$ & $211.5 \pm 1.43^{* * *}$ & $225.6 \pm 0.57^{* * * *}$ & $304.9 \pm 0.90^{* * * *}$ & $0.89 \pm 0.06^{* * *}$ & $0.43 \pm 0.01^{* * *}$ & $98.13 \pm 0.93^{*}$ & $8.35 \pm 0.06^{* * * *}$ \\
\hline P2 EA & $(100 \mathrm{mg} / \mathrm{kg})$ & $187.5 \pm 0.47^{* * *}$ & $216.5 \pm 0.61^{* * *}$ & $286.4 \pm 0.81^{* * * *}$ & $0.94 \pm 0.04^{* *}$ & $0.35 \pm 0.01^{* * *}$ & $96.91 \pm 1.46^{* *}$ & $8.207 \pm 0.02^{* * *}$ \\
\hline P2 nB & $(50 \mathrm{mg} / \mathrm{kg})$ & $203.5 \pm 1.5^{* * *}$ & $266.6 \pm 0.75^{*}$ & $313.9 \pm 0.71^{*}$ & $0.82 \pm 0.07^{* * *}$ & $0.47 \pm 0.05^{* *}$ & $80.02 \pm 0.55^{* * *}$ & $8.768 \pm 0.13^{*}$ \\
\hline P2 nB & $(100 \mathrm{mg} / \mathrm{kg})$ & $179.0 \pm 1.05^{* * *}$ & $256.3 \pm 0.69^{* * * *}$ & $283.5 \pm 0.70^{* * * *}$ & $0.77 \pm 0.01^{* * *}$ & $0.33 \pm 0.01^{* * *}$ & $72.39 \pm 0.63^{* * *}$ & $8.227 \pm 0.02^{* * *}$ \\
\hline
\end{tabular}

Each value represents Mean \pm S.E.M $(\mathrm{n}=6) * p<0.05, * * p<0.01, * * * p<0.001$ compared to $\mathrm{CCl}_{4}$ treated group. One-way ANOVA followed by Tukey's multiple comparison tests. 


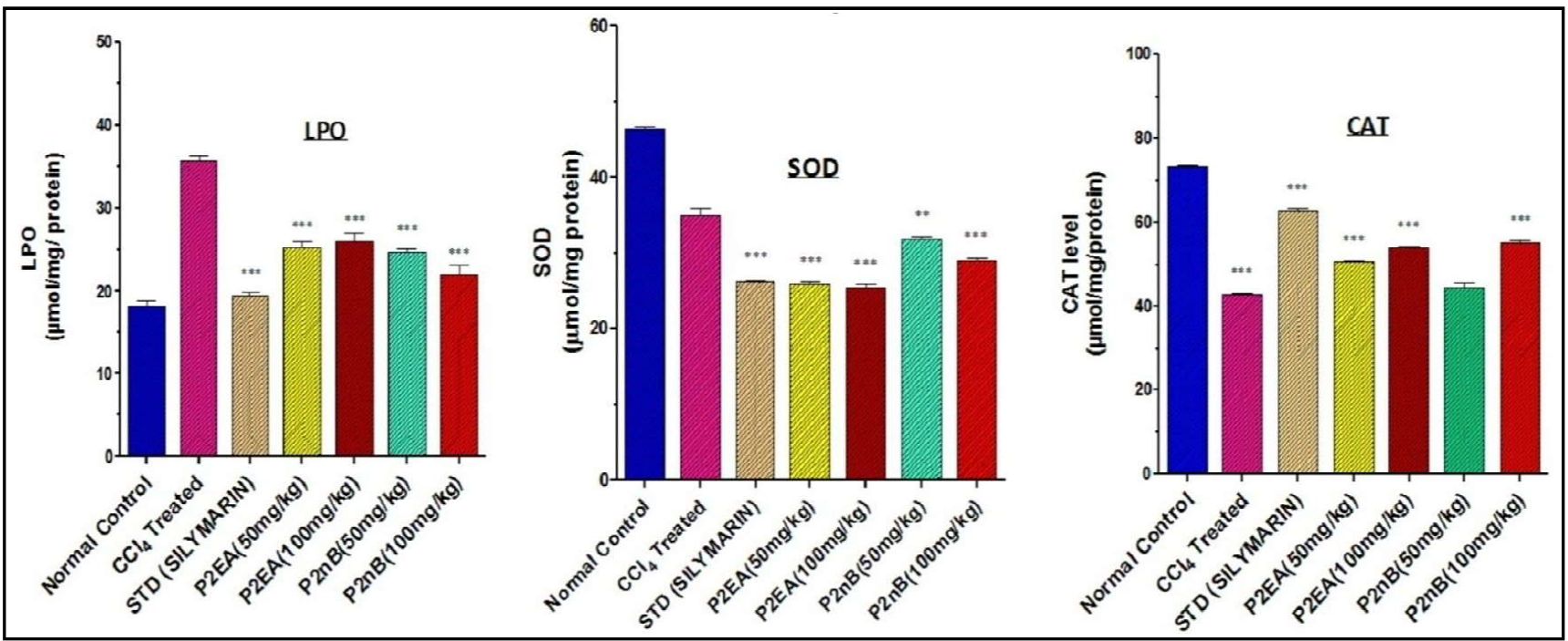

Figure 2: Effect of P2EA and $\mathrm{P} 2 \mathrm{nB}$ on endogenous antioxidant levels in $\mathrm{CCl} 4$ treated hepatotoxic rats

Each value represents Mean \pm SEM $(\mathrm{n}=6) * p<0.05, * * p<0.01, * * * p<0.001$ compared to $\mathrm{CCl}_{4}$ treated group. One-way ANOVA followed by Tukey's multiple comparison tests.

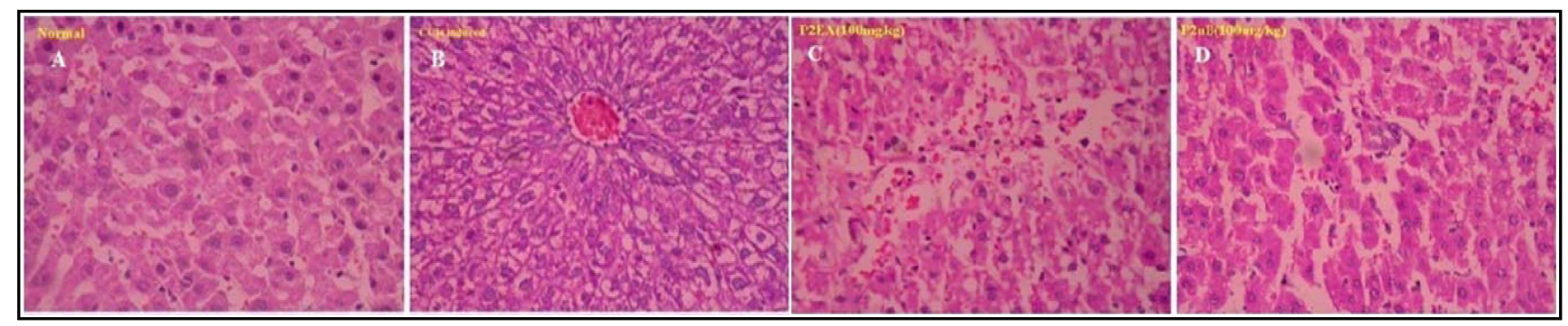

Figure 3: Microscopic evaluation of P2EA and P2nB on CCl4 induced acute hepatotoxicity (200 X stained with Haematoxylin and Oesin)

(A) Normal rats (B) $\mathrm{CCl}_{4}$ treated rats showing massive fatty accumulation, centrilobular necrosis, ballooning degeneration, infiltrating lymphocytes and loss of cell boundaries. (C) P2EA $\left(100 \mathrm{mg} / \mathrm{kg}+\mathrm{CCl}_{4}\right.$ showing normal lobular pattern with mild fatty degeneration and reduction in necrosis (D) $\mathrm{P} 2 \mathrm{nB}\left(100 \mathrm{mg} / \mathrm{kg}+\mathrm{CCl}_{4}\right.$ showing normal lobular pattern with mild fatty degeneration and reduction in necrosis.

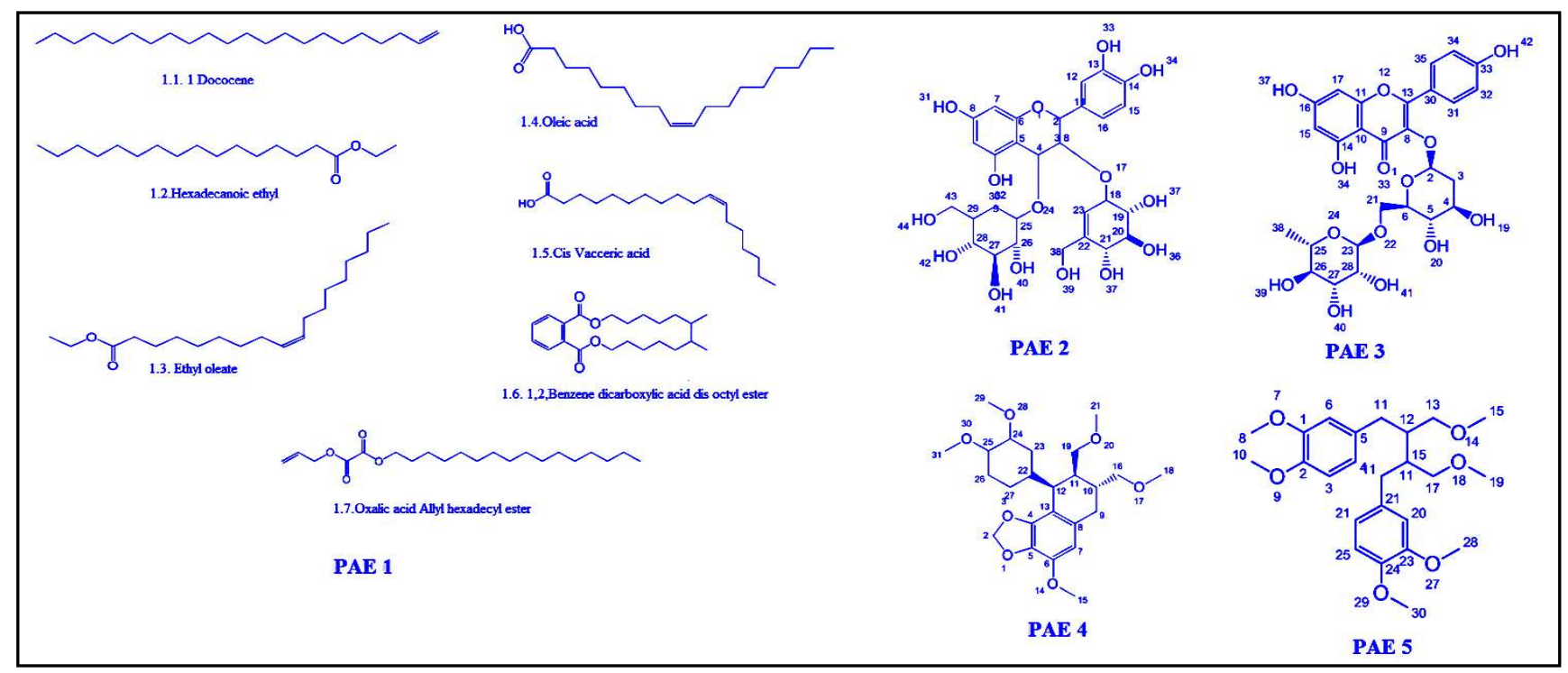

Figure 4: Secondary metabolites from ethyl acetate fraction of endophytic Nigrospora sp. CMH2_13

PAE 1- An orange oil containing seven constituents, PAE 2- quercetin-3,4'-di-O-glucoside; PAE 3- kempferol-3-O-rutinoside; PAE 4- hypophyllanthin; PAE 5- phyllanthin. 


\subsubsection{Kaempferol-3-O-rutinoside (PAE-3)}

Kaempferol-3-O-rutinoside was obtained as yellow crystals, MP: $205^{\circ} \mathrm{C}-210^{\circ} \mathrm{C} ; \mathrm{R}_{f}: 0.86\left(\mathrm{CHCl}_{3}: \mathrm{EA}, 80: 20\right)$; IR (KBR) $\mathrm{cm}^{-1}$ : 3369.64 (br. OH), 2933.73 ( $\mathrm{CH}$ str. of $\mathrm{CH}_{3}$ ), 2865.36 (CH str. of $\left.\mathrm{CH}_{2}\right), 1651.07(\mathrm{C}=\mathrm{C}$ str. of Aromatic ring $), 1606.10(\mathrm{C}=\mathrm{C}$ str. of Aromatic ring), 404.18 ( $\mathrm{CH}$ deformation in $\left.\mathrm{CH}_{3}\right) ;{ }^{1} \mathrm{H}$ NMR (DMSO $\left.\mathrm{D}_{6}\right)$ : (500 MHZ, $\delta$ ppm); 12.91 (br, s, 1H, C $\left.-\mathrm{OH}\right), 10.16$ (br, s, 1H$\left.\mathrm{C}_{7}-\mathrm{OH}\right), 6.98\left(\mathrm{~s}, 2 \mathrm{H}, \mathrm{C}_{3}, \mathrm{C}_{5}-\mathrm{H}\right), 6.51(\mathrm{t}, 1 \mathrm{H}, \mathrm{C}-6), 6.21(\mathrm{~d}, 1 \mathrm{H} \mathrm{C}-\mathrm{H})$; $6.16\left(\mathrm{~d}, 1 \mathrm{H} \mathrm{C}_{1}-\mathrm{H}\right), 3.31\left(\mathrm{~s}, 1 \mathrm{H} \mathrm{C}_{2}-\mathrm{H}\right), 3.383\left(\mathrm{~s}, 1 \mathrm{H}, \mathrm{C}_{3}-\mathrm{H}\right), 3.50(\mathrm{~s}$, $\left.1 \mathrm{H}, \mathrm{C}_{4}-\mathrm{H}\right), 3.41\left(\mathrm{~s}, 1 \mathrm{H}, \mathrm{C}_{5}-\mathrm{H}\right), 3.93\left(\mathrm{~d}, 1 \mathrm{H}, \mathrm{C}_{6 \mathrm{a}}-\mathrm{H}\right), 3.59\left(\mathrm{~s}, 1 \mathrm{H} \mathrm{C}_{6 \mathrm{~b}}-\right.$ $\mathrm{H}) ; 3.94\left(\mathrm{~d}, 1 \mathrm{H} \mathrm{C}_{1}-\mathrm{H}\right), 3.41\left(\mathrm{~s}, 1 \mathrm{H} \mathrm{C}_{2}-\mathrm{H}\right), 3.93\left(\mathrm{~s}, 1 \mathrm{H} \mathrm{C}_{3}-\mathrm{H}\right), 2.51(\mathrm{~m}$, $\left.1 \mathrm{H} \mathrm{C}_{4}-\mathrm{H}\right), 3.93\left(\mathrm{~s}, 1 \mathrm{H} \mathrm{C}_{5}-\mathrm{H}\right), 1.12\left(\mathrm{~s}, 2 \mathrm{H} \mathrm{C}_{6}-\mathrm{H}\right) ;{ }^{13} \mathrm{C}$ NMR $\left(\right.$ DMSOD $\left._{6}\right)$ : (100 MHZ, $\delta$ ppm); 184.46, 169.33, 162.49, 159.01, 152.93, 150.72, $140.70,117.22,110.22,108.11,105.73,103.85,100.88,97.28$, 96.97, 76.28, 74.46, 71.18, 70.10, 61.95, 61.50, 20.62; Mass spectra: ESI-MS: found: $595.14\left(\mathrm{M}^{+}+1\right)$, calculated: $594.52\left(\mathrm{M}^{+}\right)$.

\subsubsection{Hypophyllanthin (PAE-4)}

Hypophyllanthin was obtained as brown powder, MP: $128^{\circ} \mathrm{C}-130^{\circ} \mathrm{C}$; Rf: 0.29 (EA, 100\%); IR (KBR) cm $\mathrm{cm}^{-1} ; 2918$ (CH str. of $\left.\mathrm{CH}_{3}\right), 2850.79$ $\left(\mathrm{CH}\right.$ str. of $\left.\mathrm{CH}_{2}\right), 1656.85(\mathrm{C}=\mathrm{C}$ str. of Aromatic ring $), 1440.83(\mathrm{CH}$ deformation in $\left.\mathrm{CH}_{3}\right)$; ${ }^{1} \mathrm{H}$ NMR (DMSO D $)$ : $\left(500 \mathrm{MH}_{\mathrm{Z}}, \delta \mathrm{ppm}\right)$ : 7.998 (d, 1H, CH, C-7), 7.536 (d, 1H, CH, C-23), 6.997 (d, 1H, CH, C-26), 6.53 (d, 1H, CH, C-27), 5.838-5.844 (d, 2H, $\left.\mathrm{OCH}_{2}, \mathrm{C}-16\right)$, 4.030-4.848 (m, 1H, CH, C-12), $3.816\left(\mathrm{~s}, 3 \mathrm{H}, \mathrm{OCH}_{3}, \mathrm{C}-15\right), 3.802$ (s, $\left.3 \mathrm{H}, \mathrm{OCH}_{3}, \mathrm{C}-18\right), 3.673$ (s, $\left.3 \mathrm{H}, \mathrm{OCH}_{3}, \mathrm{C}-21\right), 3.417$ (s, $3 \mathrm{H}, \mathrm{OCH}_{3}$, C-29), 3.406 (s, 3H, $\left.\mathrm{OCH}_{3}, \mathrm{C}-31\right), 3.313-3.505$ (m, $\left.2 \mathrm{H}, \mathrm{CH}_{2}, \mathrm{C}-9\right)$, 3.025-3.187 (m, 2H, CH,$~ C-19), 2.501-2.515$ (m, 2H, Ar- $\left.\mathrm{CH}_{2}, \mathrm{C}-7\right)$, $1.548\left(\mathrm{~s}, 2 \mathrm{H}, \mathrm{CH}_{2}, \mathrm{C}-2\right), 1.096-1.063(\mathrm{~m}, 1 \mathrm{H}, \mathrm{CH}, \mathrm{C}-11),{ }^{13} \mathrm{C} \mathrm{NMR}$ (DMSOD $)$ : $\left(100 \mathrm{MH}_{\mathrm{Z}}\right) ; 40.48,54.92,71.61,31.76,73.90,39.48$, 130.55, 103.08, 136.50, 133.28, 167.40, 118.77, 136.47, 109.36, 147.92, 168.75, 119.02, 124.11, 58.67,57.4, 56.48, 54.92, 55.23, 98.78; Mass spectra: ESI-MS: $432.18(\mathrm{M}+2 \mathrm{H})$.

\subsubsection{Phyllanthin (PAE-5)}

Phyllanthin was obtained as brown powder, MP: $96^{\circ} \mathrm{C}-97^{\circ} \mathrm{C} ; \mathrm{R}_{f}: 0.24$ (EA:MeOH, 95:5); IR (KBR) cm ${ }^{-1}: 2914.44$ (Ar-C-H), 1465.90 (C-OC), 1276.88 (C-O-C); ${ }^{1} \mathrm{H}$ NMR (DMSO D 6 ): $\left(500 \mathrm{MH}_{\mathrm{Z}}\right.$ ); 7.05-6.96 (m, 3H, $\left.\mathrm{C}_{22}, \mathrm{C}_{25}, \mathrm{C}_{26}-\mathrm{H}\right), 6.62-6.57\left(\mathrm{~m}, 3 \mathrm{H}, \mathrm{C}_{3}, \mathrm{C}_{6}, \mathrm{C}_{4}-\mathrm{H}\right), 4.68-3.70$ (m, 4H, $\left.\mathrm{C}_{11}, \mathrm{C}_{13}, \mathrm{C}_{17}, \mathrm{C}_{20}-\mathrm{H}\right), 1.34-1.18\left(\mathrm{~m}, 18 \mathrm{H}, \mathrm{C}_{8}, \mathrm{C}_{10}, \mathrm{C}_{15}, \mathrm{C}_{19}\right.$, $\left.\mathrm{C}_{28}, \mathrm{C}_{30}-\mathrm{H}\right), 0.81-0.71\left(\mathrm{~m}, 2 \mathrm{H}, \mathrm{C}_{12}, \mathrm{C}_{16}-\mathrm{H}\right) ;{ }^{13} \mathrm{C}$ NMR (DMSOD 6$)$ $\left(100 \mathrm{MH}_{\mathrm{Z}}\right) ; 148.78,147.84,133.28,124.11,118.77,109.31,72.96$, 58.67, 56.48, 55.23, 39.51; Mass spectra; ESI-MS: Mass calculated as 418.53; Mass found: $417.6\left(\mathrm{M}^{-1}\right)$.

\section{Discussion}

Endophytes are any of the micro-organisms that populate within the plants without causing any immediate negative effects and found in all types of vascular plants (Hodkinson et al., 2019). The major role of endophytes is plant growth promotion, plant fitness nitrogen fixation, phosphate solubilization, and protection against pathogens and abiotic stress (Loiret et al., 2004; Taechowisan et al., 2012; Shahzad et al., 2018; Ikram et al., 2018). They are synergistic to their host and some of them are useful to the plant by producing chemically diversified secondary metabolites that prevent the host from being attacked by phytopathogens (Garyali et al., 2013). The biological/pharmacological activities of endophytic fractions and or their metabolites are also well documented (Kumar et al., 2013; Kusari et al., 2009; Eyberger et al., 2006). Ethyl acetate extract of endophytic fungus Achaetomium sp., depicted hepatoprotective activity in $\mathrm{CCl}_{4}$ exposed HepG2 cells (Uma Anitha and Mythili, 2017). In continuation of our work in search of antioxidant and liver protective compounds from endophytic fungi, an endophytic fungus (PALF-2) was isolated from the leaves of $P$. amarus leaves. Molecular techniques followed in the current study identified the fungus as Nigrospora sp. CMH2_13. Nigrospora sphaerica is an airborne filamentous fungus in the phylum Ascomycota. It is found in soil, air, and plants as a leaf pathogen. It can occur as an endophyte where it produces antiviral and antifungal secondary metabolites (Webster, 1952; Zhang et al., 2009). Authors have also reported four antifungal compounds from Nigrospora sp. LLGLM003, an endophytic fungus from the roots of Moringa oleifera Lam (Zhao et al., 2012). Oxidative damage is an etiological factor in chronic human diseases. The liver is one of the major organs attacked by ROS by damaging hepatic cells. Hepatotoxicity of $\mathrm{CCl}_{4}$ is well documented in both animals and humans and is used extensively for evaluating the liver protective activity of synthetic and natural products (Ingawale et al., 2014; Dong et al., 2016). In the $\mathrm{CCl}_{4}$ treated group, the levels of ALT, AST, ALP, direct bilirubin, total bilirubin, triglycerides and protein were elevated as compared to normal.

Cytochrome P-450 in endoplasmic reticulum activates $\mathrm{CCl}_{4}$ to trichloromethyl radicals $\left(\mathrm{CCl}_{3}^{*}\right)$. The covalent binding of the $\mathrm{CCl}_{3} *$ radical initiates the inhibition of lipoprotein secretion causing steatosis, whereas reaction with oxygen, forms trichloromethyl radicals initiating lipid peroxidation (Meharie et al., 2020). It also generates structural changes in the endoplasmic reticulum, mitochondria and protein synthesis reduction causing liver disorders (Ahsan et al., 2009). Treatment with P2EA, P2nB (50 mg/kg and $100 \mathrm{mg} / \mathrm{kg}$ ) and silymarin treated rats restored the elevated biochemical parameters when compared to $\mathrm{CCl}_{4}$ treated group rats which give increased protection of the liver

Lipid peroxidation elevation was also observed in $\mathrm{CCl}_{4}$ induced hepatotoxicity which is mainly attributed to increase malondialdehyde (MDA), a lipid peroxidation product in the liver of rats. Enhanced lipid peroxidation was observed in $\mathrm{CCl}_{4}$ induced group by elevation in TBARS level leading to damaging of tissue and antioxidant defence mechanism failure and finally cell death. Treatment with P2EA and $\mathrm{P} 2 \mathrm{nB}$ restored the increased lipid peroxidation levels caused by $\mathrm{CCl}_{4}$ which might be due anti TBARS action (Parmar et al., 2010). Administration of P2EA and P2nB (50 and $100 \mathrm{mg} / \mathrm{kg}$ ) showed a remarkable increase in the SOD and CAT levels (Maheswari et al., 2008). This may be due to the presence of antioxidant compounds in P2EA and P2nB. P2EA and P2nB (50 and $100 \mathrm{mg} / \mathrm{kg}$ ) administration improved significantly protein expressions of the SOD and CAT enzymes in the liver. P2EA and $\mathrm{P} 2 \mathrm{nB}(50$ and $100 \mathrm{mg} / \mathrm{kg}$ ) may have reduced the oxidative stress by 
increasing the activity and protein expression of the antioxidant enzymes in vivo. Treatment with P2EA and P2nB recovered the injured liver to normal and normal hepatic cell arrangement was seen as compared to $\mathrm{CCl}_{4}$. From these findings, it can be inferred that P2EA and P2nB significantly protected the liver from the toxic effects of $\mathrm{CCl}_{4}$ in rats. Finally, the hepatoprotective effect of Nigrospora sp. CMH2_13 can be attributed to the presence of secondary metabolites in P2EA and P2nB. Presence of phenols, flavonoids and tannins were observed in endophytic fungal extracts. Earlier studies on flavonoids reported the isolation of 2, 4dihydroxy-6-methoxy-3 5-dimethylchalcone from by an endophytic fungus Ceriporia lacerate isolated from Cleistocalyx operculatus (Wang et al., 2013). In our study, chromatographic and spectroscopic techniques led to the isolation of oil followed by flavonoids and lignans (Elsawy et al., 2019; Ezzat et al., 2020). LCMS analysis of oil revealed the presence of seven known metabolites. Isolated compounds were identified as quercetin 3, 4'di-O-glucoside, kempferol-3-O-rutinoside, hypophyllanthin and phyllanthin. Hence, it is speculated that hepatoprotective activity of P2EA and $\mathrm{P} 2 \mathrm{nB}$ may be due to the synergistic effect of these metabolites which act through inhibition of oxidative stress, pro-inflammatory response and metabolizing CYP enzymes in the liver.

\section{Conclusion}

The endophytic fungus, Nigrospora sp. has never been reported capable of producing phyllanthin, hypophyllanthin and antioxidant compounds. The present study is the first to isolate, characterize and identify phyllanthin and hypophyllanthin producing Nigrospora sp. from Phyllanthus amarus which may be valuable for basic research and industrial applications.

\section{Acknowledgements}

The authors are thankful to the President, Soniya Education Trust and Principal, SET's College of Pharmacy, Dharwad for encouragement, support and providing the necessary facilities to carry out the research work. We are also thankful to Dr. S. S. Hebbar, Department of Botany, Government PU College, Dharwad (India) for identification of the plant.

\section{Conflict of interest}

The authors declare that there are no conflicts of interest in the course of conducting the research. All the authors had final decision regarding the manuscript and decision to submit the findings for publication.

\section{References}

Ahsan, M.R.; Islam, K. M.; Bulbul, I.J.; Musaddik, M. A. and Haque, E. (2009). Hepatoprotective activity of methanol extract of some medicinal plants against carbon tetrachloride induced hepatotoxicity in rats. Eur. J. Sci. Res., 37(2):302-310.

Banerjee, D.; Maity, B.; Nag, S.K.; Bandyopadhyay, S.K. and Chattopadhyay, S. (2008). Healing potential of Picrorhiza kurroa (Scrofulariaceae) rhizomes against indomethacin induced gastric ulceration-a mechanistic exploration. BMC Comp. Alter. Med., 8:3.

Barkodia, M.; Joshi, U.; Rami, N.V. and Wati, L. (2018). Endophytes: A hidden treasure inside plant. Int. J. Chem. Stud., 6(5):1660-1665.
Brader, G.; Compant, S.; Vescio, K.; Mitter, B.; Trognitz, F.; Ma, L.J. and Sessitsch, A. (2017). Ecology and genomic insights into plant pathogenic and plant nonpathogenic endophytes. Annual Review Phytopatho., 55:61-83.

Claiborne, A. (1985). Handbook of methods for oxygen radical research. CRC Press, London, pp:283-284.

Dong, S.; Chen, Q.L.; Song, Y.N.; Sun, Y.;Wei, B.; Li, X.Y.; Hu, Y.Y.; Liu, P. and Su, S.B., (2016). Mechanisms of $\mathrm{CCl}_{4}$ induced liver fibrosis with combined transcriptomic and proteomic analysis. J. Toxicol. Sci., 41:561-572.

Elsawy, H.; Badr, G.M.; Sedky, A.; Abdallah, B.M.; Alzahrani, A.M. and AbdelMoneim, A.M. (2019). Rutin ameliorates carbon tetrachloride $\left(\mathrm{CCl}_{4}\right)$ induced hepatorenal toxicity and hypogonadism in male rats. Peer J., 7:e7011.

Eyberger, A.L.; Dondapati, R. and Porter, J.R. (2006). Endophyte fungal isolates from Podophyllum peltatum produces podophyllotoxin. J. Natural Prod., 69(8):1121-1124.

Ezzat, M.I.; Okba, M.M.; Ahmed, S.H.; El-Banna, H.A.; Prince, A.; Mohamed, S.O. and Ezzat, S.M. (2020). In-depth hepatoprotective mechanistic study of Phyllanthus niruri: In vitro and in vivo studies and its chemical characterization. PloS One, 15(1):p.e0226185.

Flohe, O. (1984). Superoxide dismutase assays. In methods in enzymology (L Packer Ed) academic press, New York, 105:93-104.

Galigher, A.E. and Kozloff, E.N. (1971). In essentials of practical microtechnique, $2^{\text {nd }}$ Edn. Lea and Febiger, Philadelphia. pp:77-79.

Garyali, S.; Kumar, A. and Reddy, M.S. (2013). Taxol production by an endophytic fungus, Fusarium redolens, isolated from Himalayan yew. J. Micro Biotech., 23(10):1372-1380.

Gupta, M, and Vaghela, J.S. (2019). Recent advances in pharmacological and phytochemistry studies on Phyllanthus amarus. Pharma. and Biosci. J., 7(1):1-8.

Hodkinson, T.R.; Doohan, F.M.; Saunders, M.J. and Murphy, B.R. (2019). Endophytes for a growing world. Cambridge University Press.

Ikram, M.; Ali, N.; Jan, G.; Jan, F.G.; Rahman, I.U. and Iqbalm A. (2018). IAA producing fungal endophyte Penicillium roqueforti Thom., enhances stress tolerance and nutrients uptake in wheat plants grown on heavy metal contaminated soils. PloS One, 13(11): e 0208150

Ingawale, D.K.; Mandlik, S.K. and Naik, S.R. (2014). Models of hepatotoxicity and the underlying cellular, biochemical and immunological mechanism(s): A critical discussion. Environ Toxicol Pharmacol., 37:118-133.

Joe, M.M.; Devaraj, S.; Benson, A. and Sa, T. (2016). Isolation of phosphate solubilizing endophytic bacteria from Phyllanthus amarus Schum and Thonn: Evaluation of plant growth promotion and antioxidant activity under salt. J. App. Res. Med. Aroma Plants, 3(2):71-77.

Kandasamy, P.; Manogaran, S.; Dhakshinamoorthy, M. and Kannan, K.P. (2017). Evaluation of antioxidant and antibacterial activities of endophytic fungi isolated from Bauhinia racemosa Lam and Phyllanthus amarus Schum and Thonn. J. Chem. Pharm. Res., 7(9):366-379.

Kandavel, D.H. and Sekar, S.O. (2015). Endophytic fungi from Phyllanthus amarus Schum. and Thonn capable of producing phyllanthin, hypophyllanthin and/or related compounds. Int. J. Pharm. Pharm. Sci., 7(5):253-257. 
Katoch, M.; Singh, G.; Sharma, S.; Gupta, N.; Sangwan, P.L. and Saxena, A.K. (2014). Cytotoxic and antimicrobial activities of endophytic fungi isolated from Bacopa monnieri (L.) Pennell (Scrophulariaceae). BMC Complem. Alter. Med., 14:52.

Kiemer, A.K.; Hartung, T.; Huber, C. and Vollmar, A.M. (2003). Phyllanthus amarus has anti-inflammatory potential by inhibition of iNOS, COX-2, and cytokines via the NF-KB pathway. J. Hepato., 38(3):289-297.

Kumar, A.; Patil, D.; Rajamohanan, PR. and Ahmad, A. (2013). Isolation, purification and characterization of vinblastine and vincristine from endophytic fungus Fusarium oxysporum isolated from Catharanthus roseus. PloS One, 8(9):e71805.

Kusari, S.; Zuhlke, S. and Spiteller, M. (2009). An endophytic fungus from Camptotheca cuminata that produces camptothecin and analogues. J. of Nat. Prod., 72(1):2-7.

Loiret, F.G.; Ortega, E.; Kleiner, D.; Ortega Rodes, P.; Rodes, R. and Dong, Z (2004). A putative new endophytic nitrogen fixing bacterium Pantoeasp. from sugarcane. J. App. Micro., 97(3):504-511.

Maheswari, C.; Maryammal, R. and Venkatanarayanan, R. (2008). Hepatoprotective activity of Orthosiphonst amineus on liver damage caused by paracetamol in rats. Jordan J. Biol. Sci., 1(3):105-108.

Meena, J.; Sharma, R.A. and Rolania, R. (2018). A review on phytochemical and pharmacological properties of Phyllanthus amarus Schum and Thonn. Inter. J. Pharma Sci. Res., 9(4):1377-1386.

Meharie, B.G.; Amare, G.G. and Belayneh, Y.M. (2020). Evaluation of hepatoprotective activity of the crude extract and solvent fractions of Clutia abyssinica (euphorbiaceae) leaf against $\mathrm{CCl}_{4}$ induced hepatotoxicity in mice. J. of Exper. Pharmaco., 9:12:137-50.

Parmar, S.R.; Vashrambhai, P.H. and Kalia, K. (2010). Hepatoprotective activity of some plants extract against paracetamol induced hepatotoxicity in rats. J. Herbal Med. Toxicol., 4(2):101-106.

Pedra, N.S.; Galdino, K.D.C.A.; da Silva, D.S.; Ramos, P.T.; Bona, N.P.; Soares, M.S.P.; Azambuja, J.H.; Canuto, K.M.; Brito, E.S.D.; Ribeiro, P.R.V. and Souza, A.S.D.Q. (2018). Endophytic fungus isolated from achyrocline satureioides exhibits selective antiglioma activity. The role of Sch-642305. Frontiers Oncology, 8:476(1-20).

Puri, S.K.; Habbu, P.V.; Kulkarni, P.V. and Kulkarni, V.H. (2018). Evaluation of endophytic fungal fractions of Andrographis paniculata (Burm. f.) Wall. Nees leaves for in vitro free radical scavenging and hepatoprotective activity. Inter. J. Res. in Pharma Sci., 9(1):1-7.
Shahzad, R.; Khan, A.L.; Bilal, S.; Asaf, S. and Lee, I.J. (2018). What is there in seeds? Vertically transmitted endophytic resources for sustainable improvement in plant growth. Front Plant Sci., 9:24.

Shukla, S.T.; Kulkarni, V.H.; Habbu, P.V.; Jagadeesh, K.S.; Patil, B.S. and Smita, D.M. (2012). Hepatoprotective and antioxidant activities of crude fractions of endophytic fungi of Ocimum sanctum Linn. in rats. Orien. Pharm. Exper. Med., 12(2):81-91.

Sowparthani, K. and Kathiravan, G. (2011). In vitro antibacterial screening of ethyl acetate extract of endophytic fungi isolated from Phyllanthus amarus (Schum and Thonn) against pathogenic bacterial strains. J. Pharma Biomed. Sci., 10(10):1-4.

Szabo, M.R.; Iditoiu, C.; Chambre, D. and Lupea, A.X. (2007). Improved DPPH determination for antioxidant activity spectrophotometric assay. Chem. Papers, 61(3):214-216.

Taechowisan, T.; Chanaphat, S.; Ruensamran, W. and Phutdhawong, W.S. (2012). Antifungal activity of 3-methylcarbazoles from Streptomyces sp. LJK109; an endophyte in Alpinia galangal. J. App. Pharma. Sci., 2(3): 124

Uma Anitha, K.P.G. and Mythili, S. (2017). Antioxidant and hepatoprotective potentials of novel endophytic fungus Achaetomium sp., from Euphorbia hirta. Asian P. J. of Trop. Med., 10(6):588-593.

Wang, J.; Yao, L. and Lu, Y. (2013). Ceriporialacerata DMC1106, a new endophytic fungus: Isolation, identification and optimal medium for 2,4-Dihydroxy-6-methoxy-3 5-dimethylchalcone production. Biotechnol. Bioprocess Eng., 18:669-678.

Webster, J. (1952). Spore projection in the hyphomycete Nigrospora sphaerica. New Phytologist, 51(2):229-235.

Yoganarasimhan, S.N. (1996). Medicinal plants of India, Vol. I. Bangalore: Interline Publishing Pvt, Ltd. pp:361.

Zhang, Q.H.; Tian, L.; Zhou, L.D.; Zhang, Y.; Li, Z.F.; Hua, H.M. and Pei, Y.H. (2009). Two new compounds from the marine Nigrospora sphaerica. J. of Asian Natural Products Res., 11(11):962-966.

Zhao, J.H.; Zhang, Y.L.; Wang, L.W.; Wang, J.Y. and Zhang, C.L. (2012). Bioactive secondary metabolites from Nigrospora sp. LLGLM003, an endophytic fungus of the medicinal plant Moringa oleifera Lam. World J. Microbio. Biotech., 28(5):2107-2112.

Zubair, M.F.; Atolani, O.; Ibrahim, S.O.; Adebisi, O.O.; Hamid, A.A. and Sowunmi, R.A. (2017). Chemical constituents and antimicrobial properties of Phyllanthus amarus (Schum and Thonn). Bay J. Pur. App. Sci., 10(1):238-246.

Citation Smita K. Puri, Prasanna V. Habbu, Preeti V. Kulkarni, Arun B. Joshi, V. H. Kulkarni and Sheshagiri R Dixit (2020). Hepatoprotective activity and constituents of Nigrospora SP. CMH2_13: An endophytic fungus isolated from leaves of Phyllanthus amarus Schum and Thonn. Ann. Phytomed., 9(2):239-246. http://dx.doi.org/10.21276/ap.2020.9.2.22 